\title{
MEDIA SOSIAL SEBAGAI SARANA EKSISTENSI DIRI (Reception Analysis Mahasiswa Fakultas Ilmu Komunikasi Universitas Mercu Buana Angkatan 2016)
}

\author{
Finy F. Basarah \\ Fakultas Ilmu Komunikasi, Universitas Mercu Buana, Jakarta \\ E-mail: finy_fb@yahoo.com
}

\begin{abstract}
The existence of social media made it easier for anyone to publish any activities in any social medias they had.

This activity seemed to indicate the desire to be acknowledged by others for the existence of people who actively published each activity.

Using the theory of Encoding-Decoding from Stuart Hall, Existentialist Theory of

Jean Paul Sartre, and the method of Reception Analysis, 8 (eight) Faculty of

Communication Mercu Buana University's students, class of 2016, gave a view how

they produced the meaning of each social media content produced by themselves.

The result of this research was not everyone who actively used social media to publish was an existentialist. 1 (one) out of 8 (eight) informants in this study did not belong

to any modes in which Sartre is located, 3 (three) informants belonged to the two modes, 2 (two) people belonged to Being-in-itself, 1 (one) person belonged to Beingfor-itself, and 1 (one) person belonged to Being-for-others.
\end{abstract}

Keywords: Social Media, Existence, Existentialist, Encoding-Decoding, Reception Analysis

\begin{abstract}
Abstrak
Keberadaan media sosial memudahkan siapapun untuk mempublikasikan setiap kegiatan di sejumlah media sosial yang dimilikinya. Kegiatan ini seolah menunjukkan adanya keinginan untuk diakui oleh orang lain akan eksistensi orang yang aktif mempublikasikan setiap kegiatannya tersebut. Dengan mempergunakan teori Encoding-Decoding dari Stuart Hall, Teori Eksistensialis dari Jean Paul Sartre, dan metode Reception Analysis, terpilih 8 (delapan) orang mahasiswa Fikom Universitas Mercu Buana angkatan 2016 yang telah memberikan pandangan bagaimana mereka memproduksi makna dari setiap konten media sosial yang diproduksi sendiri. Hasil

penelitian yaitu tidak semua orang yang aktif menggunakan media sosial untuk mempublikasikannya adalah seorang eksistentialis. 1 (satu) dari 8 (delapan) informan dalam penelitian ini tidak termasuk ke dalam modus cara berada Sartre manapun, 3 (tiga) orang informan termasuk ke dua modus cara berada, 2 (dua) orang termasuk ke dalam modus cara berada Being-in-itself, 1 (satu) orang termasuk ke dalam modus cara berada Being-for-itself, dan 1 (satu) orang termasuk ke dalam modus cara berada Being-for-others.
\end{abstract}

Kata Kunci: Media Sosial, Eksistensi, Eksistensialis, Encoding-Decoding, Reception Analysis. 


\section{PENDAHULUAN}

\section{Latar Belakang Masalah}

Sebuah kreativitas hanyalah sebuah karya biasa apabila hanya "disimpan" sendiri. Berbeda halnya apabila dipublikasikan melalui, salah satunya adalah media sosial. Dengan segala konsekuensinya, publikasi melalui media sosial ini masih tetap dilakukan, khususnya oleh kalangan muda. Menjamurnya media sosial, yang mengikuti perkembangan teknologi komunikasi internet, saat ini masih tetap diminati, khususnya di Indonesia sendiri.

Kominfo melalui lama kominfo.go.id pada 7 November 2013 menyebutkan bahwa pengguna internet di Indonesia mencapai 63 Juta orang, di mana 95\% diantaranya menggunakan internet untuk mengakses media sosial. Indonesia menempati peringkat ke-4 pengguna Facebook terbesar setelah USA, Brazil, dan India, dan peringkat ke-5 pengguna Twitter terbesar setelah USA, Brazil, Jepang, dan Inggris. Selain itu, media sosial yang dikenal di Indonesia adalah Path, Line, Google+, dan Linkedlin¹.

Pada 8 September 2016, Tribun Jateng melalui laman jateng.tribunnews.com memberitakan 10 (sepuluh) media sosial yang paling banyak diminati di dunia, dengan urutan sbb.2:
1. Facebook: 1.65 Miliar pengguna
2. Wechat: 1.12 Miliar pengguna
3. YouTube: 1 Miliar pengguna
4. WhatsApp: 900 Juta pengguna
5. Instagram: 400 Juta pengguna
6. Linkedlin: 300 Juta pengguna
7. Twitter: 320 Juta pengguna
8. Snapchat: 100 Juta pengguna
9. Pinterest: 100 Juta pengguna
10. MySpace: 50.6 Juta pengguna

Namun, walaupun demikian, ada juga pengguna media sosial yang hanya menginginkan "pengakuan" dari orang lain, atau masyarakat luas, mengenai dirinya dan keberadaannya. Melalui media sosial, pengguna seakan ingin menunjukkan jati diri sekaligus pengakuan dari pihak lain mengenai apa yang telah dilakukannya. Semakin banyaknya pengikut atau followers (pada Twitter dan Instagram), misalnya, menunjukkan bahwa semakin banyak pula yang mengetahui keberadaan dan mengakui keberadaan pengguna tersebut.

"Pengakuan" yang diterima seorang pengguna aktif di media sosial YouTube, misalnya, melalui www.youtube.com, tidak hanya dengan cara menerima sejumlah "Like" ataupun komentar positif, namun juga banyaknya "Subscribe" atau pengikut setia yang akan selalu menerima notifikasi setiap pengguna yang ia ikuti atau "follow" mempublikasikan sesuatu.

\footnotetext{
${ }^{1}$ https://kominfo.go.id/index.php/content/detail/3415/Kominfo+\%3A+Pengguna+Internet+di+Indonesia+63+Juta+ Orang/0/berita_satker. Diakses pada 19.10.17 pukul 11.24 WIB

2 jateng.tribunnews.com/2016/09/08/10-media-sosial-dengan-pengguna-terbesar-medsos-favorit-anda-peringkatberapa. Diakses pada 19.10.17, pukul 11.14 WIB.
} 
Berikut contoh akun YouTube dari artis muda Aurelie Hermansyah:

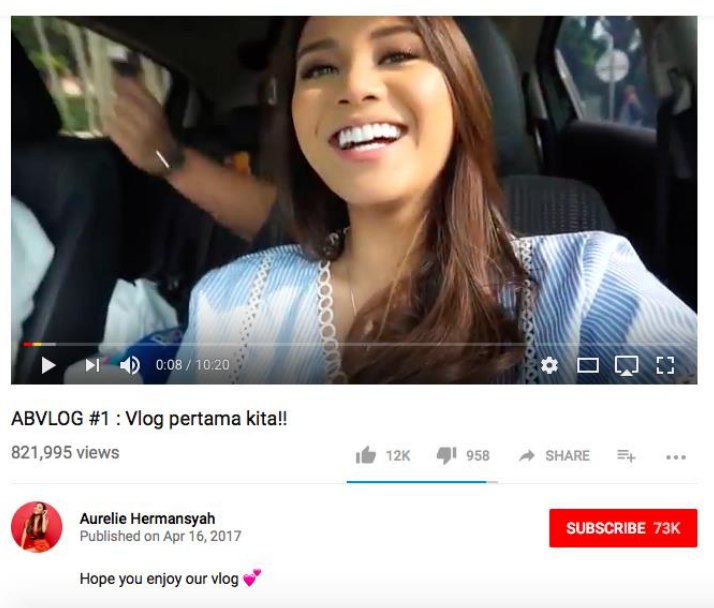

Gambar 1

Akun YouTube Aurelie Hermansyah

Dari tampilan tersebut di atas terlihat bahwa Aurelie memiliki pengikut setia sejumlah 73.000-an, dan videonya sendiri sudah dilihat sebanyak $821.995 \mathrm{kali}$, dengan jumlah “Like” sebanyak 12.000-an. ${ }^{3}$

Contoh lain dari akun Instagran seorang selebgram bernama Karin Novilda:

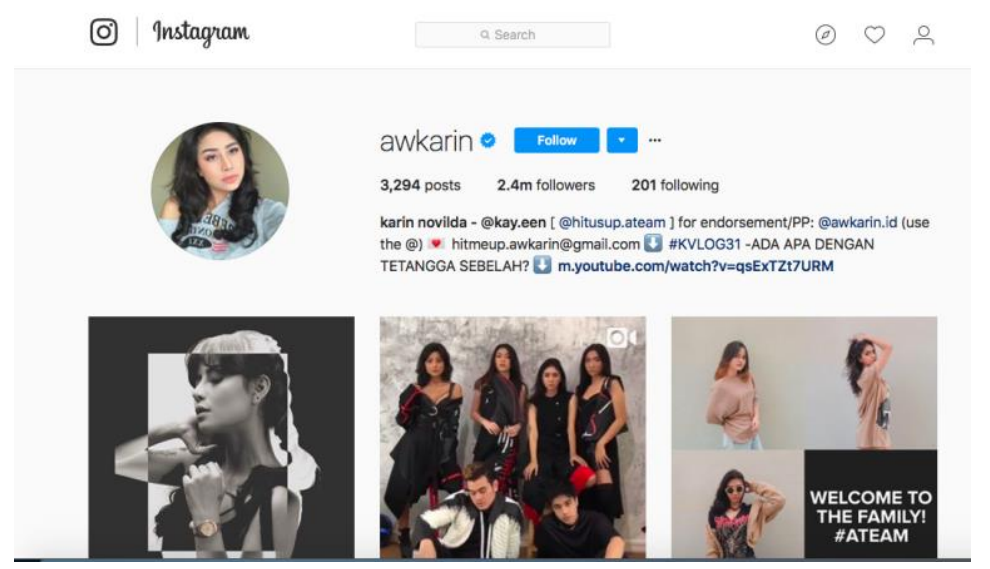

Gambar 2

Akun Instagram Karin Novilda

Karin Novilda sendiri memiliki pengikut setia sejumlah 2.4 juta-an akun dan akun YouTube-nya sendiri sudah si-subcribe oleh sebanyak 334.000-an. ${ }^{4}$

Bukan hanya aktif oleh yang bersangkutan, namun bisa juga melalui pihak lain, seperti selebgram Tatan Sugianto yang mana akun Instagramnya dipegang oleh kakak kandungnya sendiri. Dari Instagram Tatan merambah ke media sosial LINE melalui stiker Baby Tatan ${ }^{5}$.

\footnotetext{
3 Gambar diambil pada tanggal 22 Oktober 2017 pukul 18.23 WIB, melalui https://www.youtube.com/watch?v=ak-1SmfPJAs.

4 Gambar 1.2 diambil pada tanggal 22 Oktober 2017 pukul 18.40 WIB melalui https://www.instagram.com/awkarin/

${ }^{5}$ Gambar diambil pada tanggal 22 Oktober 2017 pukul 18.49 WIB melalui https://www.instagram.com/jrsugianto/
} 


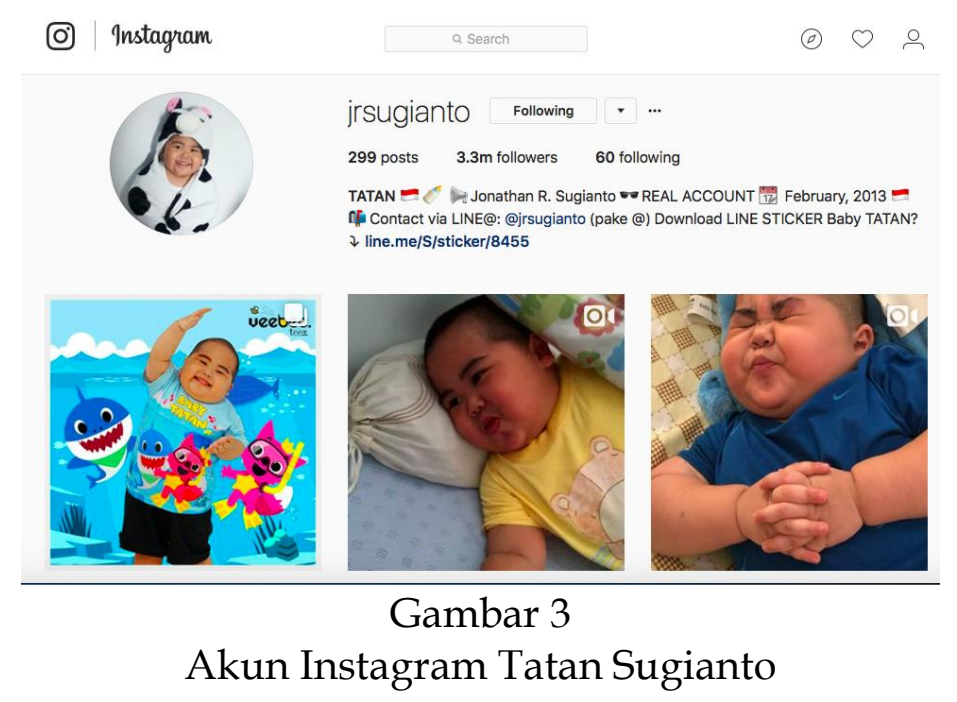

Tidak harus menjadi seorang artis ataupun selebritas apabila ingin mempublikasikan karya lewat media sosial. Bahkan, melalui media sosial seseorang bisa menjadi terkenal dan bahkan mendapatkan kesempatan untuk menjadi model sebuah produk dengan cara endorse alias mempromosikan suatu produk di akun (biasanya Instagram) atas kesepakatan dengan produsen. Cara mempromosikannya bisa dengan mengkonsumsi langsung produk yang bersangkutan disertai keterangan di bawahnya (caption) dan juga men-tag akun Instagram produk tersebut. Dengan cara demikian diharapkan followers atau pengikut tertarik untuk membeli dan mengkonsumsi produk yang sama.

Tidak usah terlalu jauh melihat ke arah mereka yang memang sudah mempunyai "nama besar" di akun media sosial. Beberapa mahasiswa Fakultas Ilmu Komunikasi (Fikom) Universitas Mercu Buana (UMB) juga ternyata aktif mempublikasikan karya mereka di media sosial. Jadi, sebagai pengguna, mereka tidak hanya mengkonsumsi dan memproduksi makna konten media sosial, namun sekaligus memproduksi pesan medianya. Apakah kegiatan memproduksi pesan media ini untuk sekedar membuat sebuah tugas kuliah maupun sebagai cara mereka ber-eksistensi. Hal tersebut yang ingin peneliti cari tahu melalui riset ini.

Dengan mempergunakan teori dasar Encoding-Decoding dari Stuart Hall (yang disesuaikan dengan situasi dan kondisinya) yang dihubungkan dengan teori eksistensialis dan metode pengumpulan data secara in-depth interview atau wawancara mendalam, riset ini bertujuan untuk mencari tahu bagaimana pengguna (yang mengkonsumsi sekaligus memproduksi pesan media sosialnya masing-masing), yaitu 8 (delapan) mahasiswa Fikom UMB yang memang aktif di media sosial, menggunakan media sosial tersebut sebagai sarana eksistensi diri mereka.

\section{Tujuan}

Tujuan penelitian ini adalah untuk mengetahui bagaimana penggunaan Media Sosial sebagai sarana Eksistensi Diri. 


\section{Definisi Konsep}

1) Media Sosial, yaitu media yang mewadahi kerja sama di antara pengguna yang menghasilkan konten

2) Eksistensi, yang berarti mengadakan pilihan-pilihan baru secara personal dan subjektif dan tidak hidup menurut pola-pola atau aturanaturan yang bersifat mekanis dan abstrak.

3) Analisis Resepsi atau Reception Analysis, di mana audiens memahami proses pembuatan makna (making meaning process) yang dilakukan oleh audiens ketika mengkonsumsi sebuah pesan media (sosial).

\section{METODOLOGI PENELITIAN}

\section{Pendekatan Riset}

Pendekatan yang dianggap sesuai dengan riset ini adalah kualitatif. Penelitian kualitatif memiliki ciri-ciri, yaitu: 1) konteks dan setting alamiah (naturalistic); 2) bertujuan untuk mendapatkan pemahaman yang mendalam tentang suatu fenomena; 3) keterlibatan secara mendalam serta hubungan erat antara peneliti dengan subjek yang diteliti; 4) teknik pengumpulan data yang khas kualitatif tanpa adanya perlakuan (treatment) atau memanipulasi variabel; 5) adanya penggalian nilai (values) yang terkandung dari suatu perilaku; 6) bersifat fleksibel; dan 7) tingkat akurasi data dipengaruhi oleh hubungan antara peneliti dengan subjek penelitian (Herdiansyah, 2013: 1623).

\section{Metode Riset}

Dalam penelitian ini akan diteliti mengenai bagaimana penggunaan Media Sosial sebagai sarana Eksistensi Diri. Metode penelitian yang digunakan untuk meneliti dan menganalisis data penelitian ini adalah analisis resepsi atau Reception Analysis.

\section{Unit Riset}

Unit analisis dalam penelitian ini adalah pernyataan atau pendapat responden dengan mempergunakan wawancara mendalam (in-depth interview) atau wawancara semi terstruktur. Adapun yang menjadi responden adalah 8 (delapan) orang mahasiswa Fikom UMB angkatan 2016.

Salah satu alasan utama mengapa wawancara semi terstruktur lebih tepat digunakan dalam penelitian kualitatif adalah karena peneliti diberi kebebasan sebebas-bebasnya dalam bertanya dan memiliki kebebasan dalam mengatur alur dan setting wawancara. Tidak ada pertanyaan yang sudah disusun sebelumnya, peneliti hanya mengandalkan guideline wawancara sebagai pedoman penggalian data (Herdiansyah, 2013: 66).

\section{Teknik Pengumpulan Data}

Untuk melengkapi pengumpulan data ini, maka peneliti memerlukan beberapa data pendukung yang bersumber dari data primer dan data sekunder, maka dari itu peneliti menggunakan dua macam teknik pengumpulan data yaitu: 
1. Data Primer, yaitu data yang diperoleh adalah wawancara mendalam sedikitnya 6 (enam) responden.

2. Data Sekunder, yaitu kumpulan data lain yang mendukung penelitian ini, yaitu studi kepustakaan (library research) yang berhubungan terhadap teori, informasi tentang hal-hal yang berkaitan dengan landasan teori, serta konsep-konsep ilmiah yang diperlukan pada saat analisis.

\section{HASIL PENELITIAN DAN PEMBAHASAN}

\section{Data Informan}

Dalam penelitian ini, terpilih 8 (delapan) orang informan, yang diantaranya atas rekomendasi dari informan yang sudah terpilih sebelumnya. Wawancara dilakukan pada hari Sabtu, 2 Juni 2018, di Universitas Mercu Buana, Gedung C lantai 2, Ruang Dosen C-206.

\section{Informan 1}

Rangga Adevio Pratama (44116010087). Instagram: @Ranggadev, YouTube: Ranngadev. Aktif di media sosial sejak 2015 lalu, "Aktif di media sosial, hmm aktifnya sih dari 2015. Kalo di instagram aktif kira-kira sejak 2015, kalau di youtube itu kira-kira sejak 2017". Rangga aktif membuat video-video di Instagram dan YouTube.

\section{Informan 2}

Indah Ramadhanty (44116010072). Instagram: @inrmdty, YouTube: Indah Ramadhanty. Aktif di media sosial sejak sekitar 2 (dua) tahun yang lalu, "Kalau aktif di media sosial sih baru sekitar 2 tahun yang lalu ya, cuma kalau buat media sosialnya udah lama. Kalau aktifnya memang 2 tahun yang lalu. Pastinya". Indah saat ini lebih aktif dalam meng-cover lagu-lagu di Instagram.

\section{Informan 3}

Tiara Gita Anggraeni (4411601088). Instagram: @tiaragtaa, YouTube: tiara channel. Aktif di media sosial sejak kelas SMP, yaitu Facebook, "Dari SMA kelas 1, kalau media sosial yang lainnya sih dari SMP, Bu, Facebook paling". Saat ini Tiara aktif di media sosial mengenai Tutorial Make-up sejak 2017, di Instagram.

\section{Informan 4}

Mutia Putri Kinanti (44116010018). Instagram: @mpkinan, YouTube: mutiakinanti. Aktif menciptakan karya di media sosial sejak 2015, "Kalau aktif di sosial media itu udah dari tahun 2012-2013, tapi kalau misalnya bener-bener aktif yang upload konten terus-terusan mulai dari SMK sih, Bu, dari 2015 itu udah mulai dicicil, tapi dulu videonya seperti belum jelas gitu, tapi saya suka buat video aja tapi kalau bener-bener yang intens yang berkonsep gitu dari tahun 2016 sih". Kinan sendiri aktif di Instagram dan YouTube mengenai cover video klip dan visualisasi puisi yang ia ciptakan sendiri, "Kalau misalnya di instagram biasanya 
saya upload teaser-nya atau trailer-nya atau video klip tapi versi satu menitnya, nah, di YouTube nya saya upload yang full-nya gitu."

\section{Informan 5}

Dini Maulidiyah (44116010085). Instagram: @Dinimaulidiyh, YouTube: Dini Maulidiyah. Aktif berkarya di media sosial sejak 2017 walaupun awalnya dilakukan secara tim sejak SMA, "Oh kalo aku sebenernya waktu SMA kan ikut teater, nah, di teater itu aku suka buat film pendek tapi memang bukan aku pribadi gitu, sih, Bu kayak kita buat produksi gitu, jadi upload-nya itu di YouTubenya teater aku, trus pas aku kuliah, sih, baru aktif di Instagram sejak 2017". Saat ini Dini aktif membuat visualisasi puisi di Instagram.

\section{Informan 6}

Marciano Pareira Laka (44116010019). Instagram: @anondarut. YouTube: marcianolaka. Aktif di media sosial sejak kelas 2 SMA, "Saya aktif di media sosial itu sejak SMA kelas 2, meng-upload karya sejak kuliah". Saat ini Ano aktif di Instagram mengenai fashion, entertainment, dan daily activity.

\section{Informan 7}

Maria Mangkung (44116010017). Instagram: @mariamangkung, YouTube: ria mangkung. Aktif di media sosial sejak berkuliah di Uniersitas Mercu Buana, "Sejak kuliah, Bu". Saat ini Maria aktif di Instagram dengan tema fashion.

\section{Informan 8}

M. Taufiqur R.A (44116010177). Instagram: @Taufiqurrahman6, YouTube: Taufik Qurahman (pribadi), Ananta Karya (tim). Secara pribadi aktif di sosial media sejak SMP, sedangkan yang menciptakan karya sejak SMA, "Kalau menciptakan karya itu sebenernya dari SMA. Ternyata saya mengenal sosial media itu bukan cuma untuk pribadi tapi bisa untuk hal-hal seperti untuk bisnis, atau untuk menyalurkan karya". Taufik memiliki akun pribadi dan juga yang dikerjakannya secara tim.

\section{Hasil Penelitian}

Dalam pemikiran Sartre, kita dapat melihat tiga modus cara berada yaitu apa yang kerap kita dengar dengan penamaan (Lubis, 2015: 253-254):

1. Being-in-itself. Ada dalam dirinya, yakni modus cara berada di mana ia sudah dikodratkan (ditentukan) seperti itu.

2. Being-for-itself. Ada untuk dirinya, memiliki cara berada di mana ada sifat negativitas, maksudnya adalah ada pengingkaran tehadap pengkodratan atau penidentikkan sesuatu yang dilekatkan kepada makhluk. Hanya manusia yang bisa mengatakan "tidak". Ketika manusia dikodratkan misalnya bersifat begini dan begitu, maka manusia dapat menolak atau menegasi pengkodratan yang dilekatkan pada dirinya - baik dengan cara mengingkari lewat pemikiran 
maupun lewat perbuatan sehingga apa yang dikodratkan tersebut ternegasi.

3. Being-for-others. Ada bagi orang lain, adalah cara berada di mana seseorang hidup berdasarkan pengkodratan (anggapan, pikiran, pengidentikkan) yang dilekatkan orang lain pada dirinya.

Hasil penelitian akan dibagi ke dalam 3 (tiga) kelompok sesuai dengan 3 (tiga) modus cara berada dari Sartre, yaitu Being-in-itself, Being-for-itself, dan Being-for-others.

\section{a) Being-in-itself.}

\section{Kesadaran Diri untuk Aktif di Media Sosial}

Informan yang menerima dirinya menyadari apa yang dibutuhkan oleh dirinya sendiri, termasuk untuk aktif di media sosial. 3 (tiga) orang informan menyadari sendiri untuk aktif di media sosial, sementara 2 (dua) orang atas inisiatif dari orang lain, dan 3 (tiga) orang terinspirasi oleh orang lain yang sudah lebih dulu aktif di media sosial. Orang lain ini bisa teman dekat, keluarga atau bahkan orang yang tidak mereka kenal sama sekali.

\section{Dominan}

Informan 2 juga atas inisiatif diri sendiri, "Sebetulnya karena memenuhi kebutuhan juga, ya, Bu, kan ada kebutuhan untuk eksis, kebutuhan untuk membranding diri. Nah, kan karena memang sekarang jamannya media sosial jadinya saya mau ngga mau mem-branding diri eksis di media sosial. Itu kebutuhan untuk aktif di media sosial bukan karena inisiatif atau motivasi dari orang lain, sih."

\section{Negosiasi}

Informan 6, "Inisiatif... dari motivasi, jadi kayak misalkan ngeliatin teman.. Kok, mereka udah berkarya, aku ngga maju-maju, sih?"

\section{Oposisi}

Informan 5 "Sebenarnya semenjak temenan ama Kinan, sih, jadi kan aku ngeliat kinan sering buat visualisasi puisi di Instagram, kata Kinan "Kenapa ngga buat visualisasi puisi juga, Din?" ya udah akhirnya semenjak itu aku coba buat visualisasi puisi kayak gitu."

\section{Kesadaran Diri Memberikan Ide di Media Sosial}

Diri yang menerima dirinya akan dengan leluasa memberikan ide sendiri untuk bisa disalurkan di media sosial. Ide-ide akan datang dari diri sendiri, sangat jarang terinspirasi dari orang lain bahkan yang total diberikan oleh orang lain. 4 (empat) orang informan menyadari akan hal itu, mereka memiliki ide sendiri untuk dipublikasikan di media sosial, sementara seorang informan malah menyalurkan ide yang justru datang dari orang lain, dan 3 (tiga) lainnya berasal dari inspirasi yang diperoleh bisa dari temannya, saudaranya, ataupun pihak lainnya.

\section{Dominan}

Informan 1, "Kalau ide-ide biasanya datang dari kehidupan sehari-hari, sih, jadi seperti sesuatu yang dirasain aja gitu, jadi seperti ditumpahin ke dalam suatu video, jadi idenya iya, dari diri sendiri".

\section{Negosiasi}


Informan 4 "Tergantung kontennya, sih, Bu, kalau visualisasi puisi biasanya sering dari diri saya sendiri. Kan saya juga tergabung di indomusik videogram, nah, di situ saya jadi terinspirasi, ini bagus, nih, kalau dibikin visual. Adegannya saya suka caricari juga referensi dari sesama orang-orang yang suka bikin video di instagram"

Oposisi

Informan 2 ide-ide justru datang dari orang lain, "Kalau ide konten, saya kan mungkin cenderung ke cover lagu, kan, kalau itu saya memang hobi nyanyi, nah teman-teman saya kan tahu, alhamdulillaah suara saya bisa dibilang ngga jelek-jelek banget lah, ya, maksudnya pantas atau layak untuk didengar. Jadi kan teman-teman saya tuh aktif juga di media sosial, melihat, men-stalking akun-akun yang cover lagu, nah mereka nyaranin saya untuk cover lagu juga biar terkenal dan bisa mungkin membuka peluang saya untuk diundang orang untuk di event-event nyanyi".

\section{Kemampuan Diri dalam Menilai Hasil Karya Sendiri}

Menerima dirinya sekaligus memiliki kepercayaan diri yang cukup tinggi. Mampu memberikan nilai yang tinggi untuk karya-karyanya merupakan hal yang menunjukkan bahwa seseorang itu bisa menilai dirinya sendiri. Walaupun hanya 1 (satu) orang yang memberikan nilai sempurna (10), namun di sini mulai nilai 8 juga bisa dibilang bahwa orang tersebut memiliki rasa percaya diri yang tinggi apabila dibandingkan dengan nilainilai di bawahnya. 2 (dua) orang informan memiliki rasa percaya diri yang tinggi, 2 (dua) orang bisa dibilang kurang memiliki rasa percaya diri, sementara 4 (empat) orang lagi memiliki rasa percaya diri yang cukup tinggi.

\section{Dominan}

Informan 7, "10, dong".

Negosiasi

Informan 6, "Karya sendiri, sih, 7.5, lah, Bu."

\section{Oposisi}

Informan 3, "Masih belum bisa dibilang bagus juga sih, tapi 5 lah paling (ketawa), ngga soalnya masih ngerasa belum bagus-bagus banget."

\section{b) Being-for-itself.}

\section{Menolak Ide atau Masukan yang Tidak Sesuai.}

Diri yang mampu menolak apa yang hendak dilabelkan oleh orang lain kepadanya, termasuk apabila ada yang memberikan ide yang tidak sesuai dengan dirinya. Ide yang mungkin akan merubah karakter atau ciri khas dari karya-karya yang sudah mereka buat dan publikasikan. 4 (empat) informan akan menolak ide atau masukan yang tidak sesuai dengan dirinya, dan 4 (empat) orang lainnya akan mencoba menampung dulu, merundingkan dahulu dengan orang yang memberikan ide untuk kemudian disesuaikan dengan dirinya sendiri.

\section{Dominan}

Informan 1, "Nggak. Jadi, saya buat sesuatu itu kalau memang saya mau. Jadi kalau saya ngga mau dan saya ngga sreg, ya saya nggak bikin."

\section{Negosiasi}

Informan 4, "Kalau aku, sih, mungkin ngga bisa langsung memutuskan langsung dikerjain apa ngga, sih, Bu, tapi aku diskusiin dulu. Tapi kalau idenya benar-benar 
ngga make sense dan misalnya memang dia ngga mau untuk mendiskusikan itu, lebih baik aku kayaknya ngga bisa buat deh, gitu".

\section{Menolak untuk Bisa Diatur oleh Orang Lain}

Ada untuk dirinya sendiri cenderung untuk menolak apabila ada yang mencoba mengatur apa yang harus dia lakukan. Pribadi ini akan lebih memutuskan sendiri termasuk dalam hal membuat dan mempublikasikan karya. 2 (dua) orang informan menyatakan bahwa mereka tidak bisa diatur, 3 (tiga) orang menyatakan bahwa mereka bisa diatur, dan lainnya bisa diatur walaupun tidak sepenuhnya.

\section{Dominan}

Informan 6, "Saya ngga bisa diatur orangnya."

Negosiasi

Informan 8, "Sebenernya bisa aja, sih, Bu, ya, tergantung, sih, situasional sebenarnya."

\section{Oposisi}

Informan 5, "Bisa kok diatur, tapi aku lebih suka diatur, sih."

\section{Menolak Respon Negatif dari Orang Lain}

Diri yang ada untuk dirinya sendiri juga akan menolak apabila ada respon negatif yang dirasa akan tidak sesuai dengan dirinya dan mengganggu kenyamanannya. Itu adalah hak pribadi karena sesuai dengan pemikiran Sartre bahwa hanya manusia yang bisa berkata "tidak", termasuk menolak apabila ada respon negatif atas karya-karya mereka. Sikap diam atau tidak merespon komentar negatif juga bisa dibilang menunjukkan adanya penolakan itu. 2 (dua) orang akan menolak, 3 (tiga) orang menerima walaupun seorang diantaranya mengatakan bahwa komen tersebut kadang menyakitkan, dan 3 (tiga) sebetulnya tidak pernah menemukan adanya komentar negatif tersebut.

\section{Dominan}

Informan 6, "Saya hapus (tertawa). Saya hapus dari sosial media saya karena komennya jelek sekali waktu itu."

\section{Negosiasi}

Informan 2, "Ngga tau sih, Bu, kalau di belakang, cuma sejauh ini yang keliatan ngga pernah sih."

\section{Oposisi}

Informan 8, "Biasanya justru jujur aja, sih, Bu, biasanya itu justru membangun saya, Bu. Saya langsung menerima dan saya langsung putar otak gimana caranya supaya orang ini suka sama apa yang bakal saya bikin selanjutnya."

\section{c) Being-for-others.}

Pengaruh dari Orang Lain dalam Membentuk Karakter atau Ciri Khas dari Karya

Diri yang ada untuk orang lain akan memengaruhi karya mereka. Mereka lebih dipengaruhi oleh orang lain untuk konten (isi) karya dibandingkan mereka yang tidak. Berkompromi salah satunya, karena dengan berkompromi berarti manerima masukan dari orang lain, artinya ada 
"unsur orang lain" yang akan memengaruhi penciptaan karya mereka. 2 (dua) orang memilih untuk lebih suka berkompromi dengan orang lain, 3 (tiga) orang akan mengedepankan keinginan mereka sendiri, dan 3 (tiga) lainnya tergantung dari jenis pekerjaannya, apakah memang pekerjaan sendiri atau pekerjaan yang dilakukan secara kelompok (tim).

\section{Dominan}

Informan 5, "Aku lebih suka lebih suka itu, sih, lebih suka kerja bareng, malah lebih seneng kerja bareng."

\section{Negosiasi}

Informan 4 "Menurut aku kalau kita tukar pikiran sama beda kepala kadang apa yang kita ngga pikirin, dipikirin sama orang, itu bisa jadi hal yang justru jadi "oh ini, nih, pointnya" jadi malah ada hal yang bisa kita ambil".

\section{Oposisi}

Informan 6, "Waktu itu, kan, pernah temen saya bilang gini, "Kamu, tuh, lucu, deh, di Instagram, kenapa sih kamu ngga buat kayak Mimi Peri?" dalam hati saya, "Memang saya Mimi Peri?" maksudnya saya, kan, mahasiswa, gitu, walaupun saya bikinnya yang lucu-lucu tapi setidaknya masih enak dipandang, kalau Mimi Peri, kan, benar-benar kalau melucu itu over."

\section{d) Rasa Tanggung Jawab atas Karya yang Dipublikasikan}

Seorang eksistensialis juga harus memiliki rasa tanggung jawab, yang dalam hal ini yaitu terhadap karya-karya yang akan atau telah dipublikasikan. Seluruh informan memiliki cara masing-masing dalam hal pertanggung jawaban atas karya yang telah dipublikasi.

\section{Informan 1}

"Saya kalau membuat sesutau itu pasti benar-benar saya pikirkan matang-matang konsepnya, mulai dari musik, takutnya masuk ke copyright atau tidak, itu saya pikirkan, atau menyinggung orang lain atau tidak, itu selalu saya pikirkan dulu. Kalau misalnya saya posting ini ada yang tersinggung nggak, ya, kalau misalnya ada, saya nggak akan pakai konsep ini. Lagu-lagu pun saya ambil yang bersih, yang free, yang no copyright."

\section{Informan 2}

"Pertanggung jawaban.. ya, mungkin selama konten aku ngga menyinggung ras, ngga berbau-bau SARA menurut aku, sih, masih aman-aman saja, karena, kan, sebelum membuat aku juga memikirkan, kan, Bu."

\section{Informan 3}

"Sebisa mungkin, sih, kalau misalnya saya mau buat konten yang terinspirasi dari, misalnya nama beauty vloggernya Sindersella, otomatis saya beri tag atau keterangan kalau saya make-up nya terinspirasi dari dia gitu, jadi bukan plagiat jatuhnya. Jadi misalnya saya re-create make-up dari Sindersella atau dari Abel, saya tag orangnya dan di slide foto selanjutnya saya taruh foto dia, kasih keterangan kalau ini, lho, yang make-up-nya saya ikutin, gitu"

\section{Informan 4}

"Saya pake hastag juga, misalnya ada namanya \#krimipandaxx, nah, dia punya ciri khasnya yaitu suka bikin pakai lampu yang LED ada pinknya, ada birunya, ada hijau toscanya. Nah, trus dia pernah bikin challenge dan saya ikutan, ya udah saya 
terinspirasi dari dia, saya tag, saya kasi hastag dia, dan segala macem, tapi tetep dengan versi saya."

\section{Informan 5}

"Kalau aku sih tulis, Bu, pake musiknya siapa, aransemennya oleh siapa."

\section{Informan 6}

"Oh, biasanya misalnya pengarah gaya atau dia yang ambil foto, saya bilang 'take by', tapi kalau misalkan inspirasi by, sih, ngga perlu, paling kalau misalnya saya udah buat karya dan banyak yang suka, saya bilang 'Oh, makasih, ini berkat kamu, lho, kemaren."

\section{Informan 7}

"Oh, itu, sebelum Maria posting pasti sudah dipikirkan, nah, dipikirkannya itu misalnya, ya, mungkin pasti nanti jawabannya ada yang suka ada yang nggak suka, nah di situ Maria sudah memikirkan matang-matang ketika yang nggak suka dihadapin kayak gimana, yang suka gimana."

\section{Informan 8}

"Biasanya, sih, saya kalau bikin karya, tuh, seoriginal mungkin semuanya dari saya, lagu saya cari yang original yang memang disediakan dari internet, kan nggak banyak, tuh, lagu yang nggak melanggar hak cipta, nah, biasanya nyari dari situ. Kalaupun saya pakai lagu orang biasanya saya tulis itu karya siapa. Sampai saat ini belum pernah, sih, dikomen 'ini lagu sama' apalagi sama penyanyinya, misalnya sama 'oh, ini bahan dari saya' atau 'lagu dari saya, nih, nggak boleh', belum pernah sih kalaupun saya sampai seperti itu, ya mungkin pasti akan saya hapus postingannya."

\section{Pembahasan}

Ketika sebuah karya dipublikasikan, rata-rata orang cenderung untuk mendapatkan respon yang baik, minimal dilihat oleh beberapa orang, baik followers maupun bukan followers (apabila akun tersebut tidak diberi privasi). Lebih dari itu, yaitu apabila ternyata karya yang telah dipublikasikan tersebut diberi "Like" atau komentar yang positif, walaupun ada juga yang memberikan komentar negatif, yang mana ditanggapi beragam oleh responden.

Modus cara berada being-in-itself artinya dia menerima kodrat atau yang telah dilekatkan kepadanya. Di sini dibutuhkan kesadaran untuk mengenal dirinya sendiri, potensi dan juga apa yang dibutuhkan oleh seseorang. Informan 1 termasuk ke kategori “Dominan" untuk ketiga pertanyaan yang diajukan, artinya dia bisa termasuk ke dalam eksistensialis yang being-in-itself. Informan 7 juga bisa termasuk ke dalam kelompok ini, karena dua dari tiga jawabannya termasuk ke kategori "Dominan". Sementara informan yang lainnya lebih beragam, yang artinya juga tidak termasuk ke dalam kelompok ini. Bahkan bisa dibilang sebetulnya rasa Percaya Diri (PD) informan 7 ini termasuk paling tinggi dibandingkan dengan informan lainnya. Di sini juga terdapat kelompok yang tidak sepenuhnya masuk ke dalam being-in-itself dengan kelompok jawaban "Negosiasi", yaitu informan 4 dan 6 . 
Being-in-itself memiliki pengertian yang sangat bertolak belakang dengan being-for-others. Dengan begitu bisa saja kelompok "Oposisi" dalam being-for-others masuk ke dalam kelompok ini ataupun kelompok being-foritself.

Sedangkan Being-for-itself sendiri adalah hal-hal yang bersifat negatif, yang artinya menolak apabila ada campur tangan orang lain. Informan yang termasuk ke dalam being-in-itself adalah informan 6, informan 7 juga bisa termasuk ke dalam kelompok ini karena menjawab dua dari tiga jawabannya termasuk ke kategori "Dominan". Sementara untuk kategori jawaban "Negosiasi" adalah informan 2, dan informan 3 juga bisa masuk ke kategori ini dengan 2 jawaban negosiasi dan 1 jawaban dominan.

Being-for-others artinya eksistensi yang tergantung dari apa yang orang lain lekatkan kepadanya, di mana informan 3 dan informan 5 termasuk ke dalam kelompok ini, dan jawaban lainnya beragam.

Dengan begitu bisa dilihat bahwa Informan 1 termasuk ke dalam eksistensialis dengan modus cara berada being-in-itself, dan informan 2 ke dalam modus cara berada being-for-itself. Sedangan informan 3 bisa masuk ke dalam being-for-others dan being-for-itself. Informan 4 masuk ke dalam being-initself, informan 5 ke dalam being-for-others, informan 6 ke dalam being-for-itself dan being-in-itself, dan informan 7 ke dalam being-in-itself dan being-for-itself. Sedangkan informan terakhir, yaitu informan 8 tidak termasuk ke dalam kelompok eksistensialis, karena tidak secara tegas maupun sebagian masuk ke dalam modus cara berada manapun.

Tabel 1

Being-in-itself

\begin{tabular}{|l|l|l|l|}
\hline \multicolumn{1}{|c|}{ Informan } & $\begin{array}{c}\text { Kesadaran Diri } \\
\text { untuk Aktif di } \\
\text { Media Sosial }\end{array}$ & $\begin{array}{c}\text { Kesadaran Diri } \\
\text { Memberikan Ide } \\
\text { di Media Sosial }\end{array}$ & $\begin{array}{c}\text { Kemampuan Diri } \\
\text { dalam Menilai } \\
\text { Hasil Karya } \\
\text { Sendiri }\end{array}$ \\
\hline Informan 1 & Dominan & Dominan & Dominan \\
\hline Informan 2 & Dominan & Oposisi & Negosiasi \\
\hline Informan 3 & Dominan & Negosiasi & Oposisi \\
\hline Informan 4 & Negosiasi & Negosiasi & Negosiasi \\
\hline Informan 5 & Oposisi & Dominan & Negosiasi \\
\hline Informan 6 & Negosiasi & Negosiasi & Negosiasi \\
\hline Informan 7 & Negosiasi & Dominan & Dominan \\
\hline Informan 8 & Oposisi & Dominan & Oposisi \\
\hline
\end{tabular}

Tabel 2

Being-for-itself

\begin{tabular}{|c|c|c|c|}
\hline Informan & $\begin{array}{c}\text { Menolak Ide } \\
\text { atau Masukan } \\
\text { yang Tidak } \\
\text { Sesuai. }\end{array}$ & $\begin{array}{c}\text { Menolak untuk } \\
\text { Bisa Diatur oleh } \\
\text { Orang Lain }\end{array}$ & $\begin{array}{c}\text { Menolak Respon } \\
\text { Negatif dari } \\
\text { Orang Lain }\end{array}$ \\
\hline Informan 1 & Dominan & Oposisi & Oposisi \\
\hline
\end{tabular}




\begin{tabular}{|l|l|l|l|}
\hline Informan 2 & Negosiasi & Negosiasi & Negosiasi \\
\hline Informan 3 & Negosiasi & Negosiasi & Dominan \\
\hline Informan 4 & Negosiasi & Oposisi & Negosiasi \\
\hline Informan 5 & Negosiasi & Oposisi & Negosiasi \\
\hline Informan 6 & Dominan & Dominan & Dominan \\
\hline Informan 7 & Dominan & Dominan & Oposisi \\
\hline Informan 8 & Dominan & Negosiasi & Oposisi \\
\hline
\end{tabular}

Tabel 3

Being-for-others

\begin{tabular}{|l|l|}
\hline \multicolumn{1}{|c|}{ Informan } & \multicolumn{1}{|c|}{$\begin{array}{c}\text { Pengaruh dari Orang Lain dalam } \\
\text { Membentuk Karakter atau Ciri Khas } \\
\text { dari Karya }\end{array}$} \\
\hline Informan 1 & Oposisi \\
\hline Informan 2 & Negosiasi \\
\hline Informan 3 & Dominan \\
\hline Informan 4 & Negosiasi \\
\hline Informan 5 & Dominan \\
\hline Informan 6 & Oposisi \\
\hline Informan 7 & Oposisi \\
\hline Informan 8 & Negosiasi \\
\hline
\end{tabular}

Tabel 4

Kelompok Eksistensialis

\begin{tabular}{|l|l|}
\hline \multicolumn{1}{|c|}{ Informan } & \multicolumn{1}{c|}{ Modus Cara Berada } \\
\hline Informan 1 & Being-in-itself \\
\hline Informan 2 & Being-for-itself \\
\hline Informan 3 & Being-for-others dan Being-for-itself \\
\hline Informan 4 & Being-in-itself \\
\hline Informan 5 & Being-for-others \\
\hline Informan 6 & Being-for-itself dan Being-in-itself \\
\hline Informan 7 & Being-in-itself dan Being-for-itself \\
\hline Informan 8 & - \\
\hline
\end{tabular}

\section{SIMPULAN}

Berikut simpulan yang bisa diperoleh dari hasil penelitian:

1. Tidak semua orang yang aktif menggunakan media sosial untuk mempublikasikan karyanya adalah seorang eksistentialis. 1 (satu) dari 8 (delapan) informan dalam penelitian ini tidak termasuk ke dalam modus cara berada Sartre manapun.

2. Adakalanya informan masuk ke dalam modus cara berada lebih dari satu. Terdapat 3 (tiga) orang informan yang masuk ke dua modus cara berada, di mana salah satunya adalah Being-for-itself.

3. Dari 8 (delapan) informan terdapat 2 (dua) orang yang masuk ke dalam modus cara berada Being-in-itself, dan 1 (satu) orang yang 
masuk ke dalam modus cara berada Being-for-itself. Sedangkan 1 (satu) orang termasuk ke dalam modus cara berada Being-for-others.

4. Walaupun usia mereka relatif muda, namun kedelapan informan ini termasuk orang yang memiliki tanggung jawab, dengan caranya masing-masing. Mereka menghindari plagiat atau mengambil hak milik orang lain. Mereka juga memikirkan dengan sebaik-baiknya sebelum memperoses, memproduksi, dan mempublikasikan karya mereka, jangan sampai mereka menyinggung pihak lain atau melanggar hukum lainnya seperti melanggar hak cipta tadi.

\section{DAFTAR PUSTAKA}

Herdiansyah, Haris. 2013. Wawancara, Observasi, dan Focus Groups Sebagai Instrumen Penggalian Data Kualitatif. Jakarta: PT RajaGrafindo Persada.

Ida, Rachmah. 2014. Metode Penelitian, Studi Media dan Kajian Budaya. Jakarta: Prenada Media Group.

jateng.tribunnews.com/2016/09/08/10-media-sosial-dengan-penggunaterbesar-medsos-favorit-anda-peringkat-berapa. Diakses pada 19.10.17, pukul 11.14 WIB.

kominfo.go.id/index.php/content/detail/3415/Kominfo+\%3A+Pengguna $+\mathrm{I}$ nternet+di+Indonesia+63+Juta+Orang/0/berita_satker. Diakses pada 19.10.17 pukul 11.24 WIB

Lubis, Akhyar Yusuf. 2015. Pemikiran Kritis Kontemporer. Jakarta: PT RajaGrafindo Persada.

Nasrullah, Rully. 2016. Media Sosial, Perspektif Komunikasi, Budaya, dan Sosioteknologi. Bandung: PT Remaja Rosdakarya.

www.instagram.com/awkarin/. Diakses pada 22.10.17 pukul 18.40 WIB.

https://www.instagram.com/irsugianto/. Diakses pada 22.10.17 pukul 18.49 WIB.

www.youtube.com/watch?v=ak-1SmfPJAs. Diakses pada 22.10.17, pukul 18.23 WIB

\section{DATA PENULIS}

Finy F. Basarah. Fakultas Hukum Universitas Parahyangan, Bandung (lulus tahun 2000), Program Pasca Sarjana Fakultas Ilmu Komunikasi Universitas Padjadjaran, Bandung (lulus tahun 2006). Bidang peminatan pada Kajian Media. Menjadi Dosen di Fakultas Ilmu Komunikasi Universitas Mercu Buana sejak tahun 2010. 